\title{
Effect of antecedent rainfall on pore-water pressure distribution characteristics in residual soil slopes under tropical rainfall
}

\begin{abstract}
Characteristics of changes in pore-water pressure distribution are the main parameters associated with slope stability analysis involving unsaturated soils, which are directly affected by the flux boundary conditions (rainfall infiltration, evaporation and evapotranspiration) at the soil-atmosphere interface. Two slopes were instrumented at Universiti Teknologi Malaysia, Skudai campus Malaysia, using Jet Fill Tensiometer. The field monitoring results were analyzed to characterize pore-water pressure distributions to study the effect of antecedent rainfall on pore-water pressure distributions in typical residual soil slopes under tropical climate. Slope stability analyses were also conducted at depth 1.0-2.0 meter and recorded in each slope to determine the range of factor of safety for the slopes. Results indicate that, antecedent rainfall; initial pore-water pressures prior to a significant rainfall event as well as the magnitude of the rainfall event play a crucial role in the development of the worst porewater pressure condition in a slope. The role of antecedent rainfall in the development of the worst pore-water pressure condition was found to be more significant in residual soils with low permeability as compared with that in residual soils with high permeability. The factor of safety of residual soils with low permeability was found to be unaffected by the worst pore-water pressure condition.
\end{abstract}

Volume 2 Issue $6-2018$

Mohamed Elbyhagi Elfadil
Bridges Department, NewTech Consulting Group, Sudan

Correspondence: Mohamed Elbyhagi Elfadil, Bridges Department, New Tech Consulting Group, Sudan, Tel +249-1835 2177 I/2/3/5, +2499 I292 605।, Fax +249 I 55 I80607, Email gazoli78@hotmail.com

Received: June 28, 2018 | Published: December 31, 2018

\section{Introduction}

Rainstorm is one of the most significant triggering factors for slope failures. The rainfall infiltration on slope will result in an increase of moisture content of the soil and hence increase the driving force. It also increases the pore water pressure and subsequently decreases the shear strength. The increase in pore water pressure is directly related to rainfall infiltration and percolation or may be the result of the formation of perched water table. It is widely recognized that rainfallinduced slope failures are mainly caused by infiltration of rainwater. ${ }^{1-4}$ A number of studies have also indicated that slope failures can be attributed to several factors such as climatic conditions, geological features, topography, vegetation or a combination of these factors. These factors and their contribution to slope instability vary with geographical locations. Some studies have attempted a simple correlation between incidences of landslides with rainfall patterns. Simple direct correlations have been made for Brazil. . $^{1,5}, 6$

More complicated correlation attempts are available for New Zealand..$^{6-9}$ Although the significance of rainwater infiltration in causing landslides is widely recognized, there have been different conclusions as to the relative roles of antecedent rainfall to landslides. ${ }^{6}$ Suggested that antecedent rainfall was not a significant factor for landslides in Hong Kong and this limited influence of antecedent rainfall was attributed to the high permeability of local soils. ${ }^{6}$ Suggested that the majority of landslides in Hong Kong were induced by localized and short duration rainfall of high intensity. ${ }^{1}$

The objectives of this study are:

a. To characterize pore water pressure distributions

${ }^{1}$ Department of Meteorology Malaysia, Ministry of Science, Technology dan Innovation (2006). Laporan Hujan Lebat Yang Mengakibatkan Banjir Di Negeri Johor, Melaka, Negeri Sembilan dan Pahang dalam Tempoh1720Disember2006. b. To evaluate the effect of antecedent rainfall on pore-water pressure distributions in two residual soil slopes under tropical climate. Such in-formation is fundamental to slope-stability-analysis and adoption of appropriate management strategies for the stability of residual soil slopes

\section{Methodology}

The study comprises the collection of field data, obtaining soil properties through field and laboratory tests and performing slope stability analysis. Field data collected from the sites are the geometry of the slope, rainfall data and matric suction. Site-1 was in-strumented with nine tensiometers while Site- 2 was instrumented with a rain gauge and 27 tensiometers (Figure 1). Suctions were monitored by the tensiometers since July 2006. Field permeability tests (Guelph Permeameter) were also conducted at the sites at depth $0.3 \mathrm{~m}$. Disturbed and Undisturbed samples were collected at depths of $0.5 \mathrm{~m}$, $1 \mathrm{~m}$ and $2 \mathrm{~m}$ at several occasions between July and December 2006 to obtain water content at normal condition and at extreme condition i.e. after the prolonged and intense rainfall on December 2006.

Laboratory tests were conducted to obtain soil index properties, shear strength parameter and the permeability of soil forming the slope. The shear strength of soil was evaluated by direct shear test due to difficulties of getting undisturbed sample at site- 2 where there is some boulders affecting undisturbed sample. All tests are performed following British Standards (BS, 1990). The soil water characteristic curves (SWCC) were obtained by pressure plate test. The apparatus and the procedure followed for obtaining the SWCC is explained in Wang and Benson (2004).

Factor of safety calculated based on SWCC and field suction records as well. To compare the results and verify that SWCC can be used to estimate the highest suction that may be reached in a soil slope and the fluctuation range of the suction Infinite slope stability 
analyses were performed for slopes at normal condition and at wettest condition using the formula proposed by references. ${ }^{10,11}$ The pore air pressure is atmospheric, the equation can be written as:

$$
F O S=\frac{C^{\prime}+\left(N-u_{w}\right) \tan \phi^{\prime}}{W \sin \beta \cos \beta} \text { (1) }
$$

where $c^{\prime}=$ effective cohesion of the soil, $\mathrm{N}=$ normal stress applied on failure surface, $\phi^{\prime}=$ effective friction angle, $\mathrm{u}_{\mathrm{a}}=$ pore air pressure, $\mathrm{u}_{\mathrm{w}}=$ pore water pressure, $\mathrm{u}_{\mathrm{a}}-\mathrm{u}_{\mathrm{w}}=$ matric suction, $\mathrm{W}=$ total weight of the soil, $\beta=$ the slope angle and $\phi_{\mathrm{b}}=$ unsaturated friction angle, Although $\phi_{\mathrm{b}}$ is generally dependent on the range of matric suction, the value approaches the effective friction angle, $\phi$ ' at low matric suction ${ }^{10,11}$. By using $\phi_{\mathrm{b}}=\phi^{\prime}$ and the pore air pressure is atmospheric, the above equation can be written as:

$$
F O S=\frac{C^{\prime}+N \tan \phi^{\prime}+\left(u_{a}-u_{w}\right) \tan \phi^{b}}{W \sin \beta \cos \beta}
$$

The survey work showed that both slopes can be considered as long slopes. The slope at Site- 1 formed an angle of $30^{\circ}$ while the slope at Site- 2 forms an angle of $20.8^{\circ}$. Field permeability test using Guelph permeameter show that the permeability coefficient of soil at Site-1 is $1.07 \times 10^{-7} \mathrm{~m} / \mathrm{sec}$ while that of Site- 2 is $1.23 \times 10^{-5} \mathrm{~m} / \mathrm{sec}$.

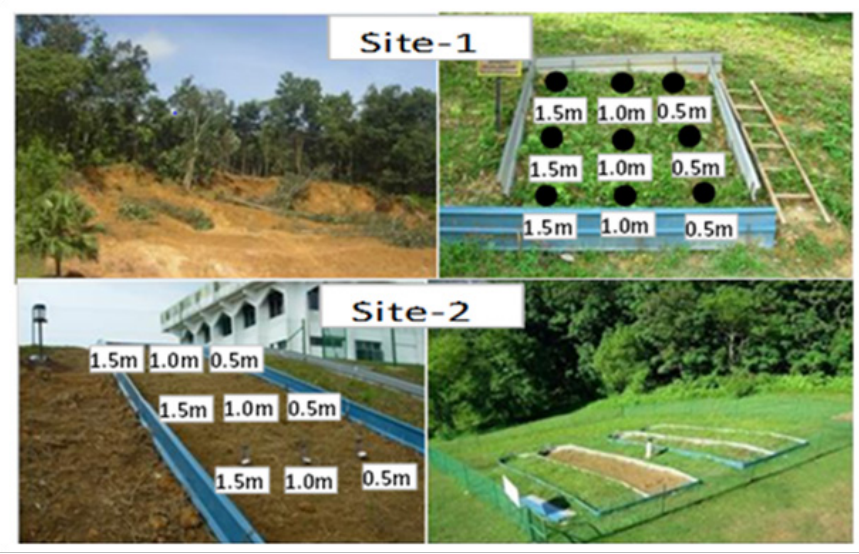

Figure I Shows Site-I (Kolej I2) Field on 20 ${ }^{\text {th }}$ December 2006 and Site-2 (Balai Cerapan) Remain Stable.

\section{Results and discussion}

The basic data for this study are the rainfall records on slope at site-2 which near the site-1, pore-water pressure measurements at various depths; $0.5,1.0,1.5$ meter at each location at the slope; crest, middle and toe during raining season and dry season conditions across the year, site-1 monitored for six months and Site-2 monitored for one year, the data were characterized two periods; wet period and dry period for each slope were further characterized by key times and the distribution of pore-water pressures along slope profile during these key times was examined.

Key times were considered to be

i. Time at the end of a prolong dry period

ii. Time following one or a series of significant rainfall event.

The summary of rainfall records are presented on the graphs. The factor of safety was calculated for the slopes using the soil properties shown in (Table 1). The rainfall data and soil suction shown in the graphs. Infinite slope procedure was used to determine the factor of safety (FOS). The calculation was made for slip planes at different depths between 1 and $2.0 \mathrm{~m}$ with the interval of $0.2 \mathrm{~m}$. Drained shear strength parameters obtained from direct shear test were used in the calculation. The results of the slope stability analysis performed for suction predicted based on water content and SWCC curve are presented in (Table 2). The soil suction monitored in each slope during key times. The subsequent analyses discussion is based on individual slopes.

\begin{tabular}{|c|c|c|c|c|c|c|}
\hline \multicolumn{3}{|c|}{ Parameter } & \multirow{2}{*}{\multicolumn{2}{|c|}{$\begin{array}{l}\text { Kolej 12 } \\
\text { (Site 1) }\end{array}$}} & \multicolumn{2}{|c|}{$\begin{array}{l}\text { Balai Cerapan } \\
\text { (Site 2) }\end{array}$} \\
\hline \multicolumn{3}{|c|}{ Unit weight $(\gamma) \mathbf{k N} / \mathbf{m} 3$} & & & 18.0 & \\
\hline \multirow{2}{*}{$\begin{array}{l}\text { Elev } \\
(\mathrm{m})\end{array}$} & \multicolumn{2}{|c|}{$\begin{array}{l}\text { Site } 1 \\
\text { Normal Condition }\end{array}$} & \multicolumn{2}{|c|}{$\begin{array}{l}\text { Site } 2 \\
\text { Normal } \\
\text { Condition }\end{array}$} & \multicolumn{2}{|c|}{$\begin{array}{l}\text { Site } 2 \\
\text { After prolonged } \\
\text { rainfall }\end{array}$} \\
\hline & $\begin{array}{l}\text { VWC } \\
\%\end{array}$ & $\begin{array}{l}\text { Suction } \\
\mathrm{kPa}\end{array}$ & $\begin{array}{l}\text { VWC } \\
\%\end{array}$ & $\begin{array}{l}\text { Suction } \\
\mathrm{kPa}\end{array}$ & $\begin{array}{l}\text { VWC } \\
\%\end{array}$ & $\begin{array}{l}\text { Suction } \\
\mathrm{kPa}\end{array}$ \\
\hline 1.0 & 57 & 70 & 32.5 & 15 & 34.8 & 9.8 \\
\hline 2.0 & 60 & 28 & 33.5 & 12.9 & 36.8 & 4.8 \\
\hline
\end{tabular}

Table I Soil properties

Table 2 Variation of Suction calculated based on SWCC curve.

\begin{tabular}{lllll}
\hline $\begin{array}{l}\text { Elev } \\
(\mathbf{m})\end{array}$ & $\begin{array}{l}\text { Site 1 } \\
\text { Normal } \\
\text { Condition }\end{array}$ & $\begin{array}{l}\text { Site 2 } \\
\text { Normal } \\
\text { Condition }\end{array}$ & $\begin{array}{l}\text { Site 2 } \\
\text { After prolonged } \\
\text { rainfall }\end{array}$ \\
\hline $\begin{array}{l}\text { Depth } \\
\mathrm{m}\end{array}$ & \multicolumn{2}{c}{ FOS (Site 1) } & \multicolumn{2}{c}{ FOS (Site 2) } \\
\cline { 2 - 5 } & Normal & December & Normal & December \\
\hline 1.0 & 5.45 & 1.14 & 4.79 & 4.08 \\
\hline 1.2 & 4.21 & 1.08 & 4.29 & 3.58 \\
\hline 1.4 & 3.33 & 1.04 & 3.94 & 3.21 \\
\hline 1.6 & 2.66 & 1.01 & 3.68 & 2.97 \\
\hline 1.8 & 2.15 & 0.99 & 3.49 & 2.86 \\
\hline 2.0 & 1.83 & 0.97 & 3.34 & 2.78 \\
\hline
\end{tabular}

(Table 1) summarizes the results of laboratory tests on disturbed samples obtained from both sites. It can be seen that sample from Site2 contains more coarse particles than the sample obtained at Site-1. The soil at Site-1 has higher silt content which makes the soil prone to the erosion and dispersion; hence the slope is prone to fail at higher water content. The soil at Site-2 is a less plastic than the soil at Site1. However, the difference is very small and it should be noted that only a small fraction of soil at Site-2 belongs to fine particles, thus the effect is very limited. Classification tests show that the soil at Site-1 is sandy silt of high plasticity (MHS) while the soil at Site-2 is silty gravel of low plasticity (GML).

The drained shear strengths of soil from both sites were obtained from direct shear test. As shown in (Table 1), the soil at Site-2 has higher shear strength than that in Site-1 especially in term of friction angle. The permeability of soil at Site- 2 is two orders of magnitude higher than that of Site-1. It is noted that the laboratory test gives lower value than the field test because the laboratory tests were performed on compacted soil. The natural volumetric water content of soil in Site-2 varies slightly from $32.5 \%$ at depth of $1 \mathrm{~m}$ to $33.5 \%$ at depth of $2 \mathrm{~m}$. The water content measured after the prolonged and intense rainfall in December 2006 is only slightly higher than the average, i.e. $34.8 \%$ and $36.8 \%$ at depth of $1 \mathrm{~m}$ and $2 \mathrm{~m}$ respectively. 
Note that the volumetric water content at saturation for soil at Site-2 is $42.4 \%$. Slight change in soil water content corresponding to depths and the rainfall is due to the presence of clay in soil. The natural volumetric water content of soil at Site-1 varies from $57 \%$ at depth of $1 \mathrm{~m}$ to slightly higher than $60 \%$ at depth of $2 \mathrm{~m}$. The water content measured a few days after the failure is $69 \%$ which is higher than the water content at saturation $64 \%$. This shows that the soil has reached saturation at the time of failure.

Besides the saturated permeability of the soil, the soil water characteristics curve (SWCC) was another important characteristic of the unsaturated soil that influences the mechanism of rainfall-induced slope failure. (Figure 2) shows the SWCC dry curves obtained by the pressure plate extractors for soil samples collected at both sites. The highest suction that may exist in a soil is limited by the suction at the residual volumetric water content. Beyond this point, the water content in the soil is hardly to be dissipated even though it is still possible. The highest suction could be recorded at Site-2, which consists of coarse grained soil, was $23 \mathrm{kPa}$ at residual water content of $30 \%$. As for the fine-grained soil, the maximum suction is very high $(>1500 \mathrm{kPa})$. However the soil loss its suction gradually during the pro-longed rainfall until the safety envelope was exceeded. ${ }^{12,13}$

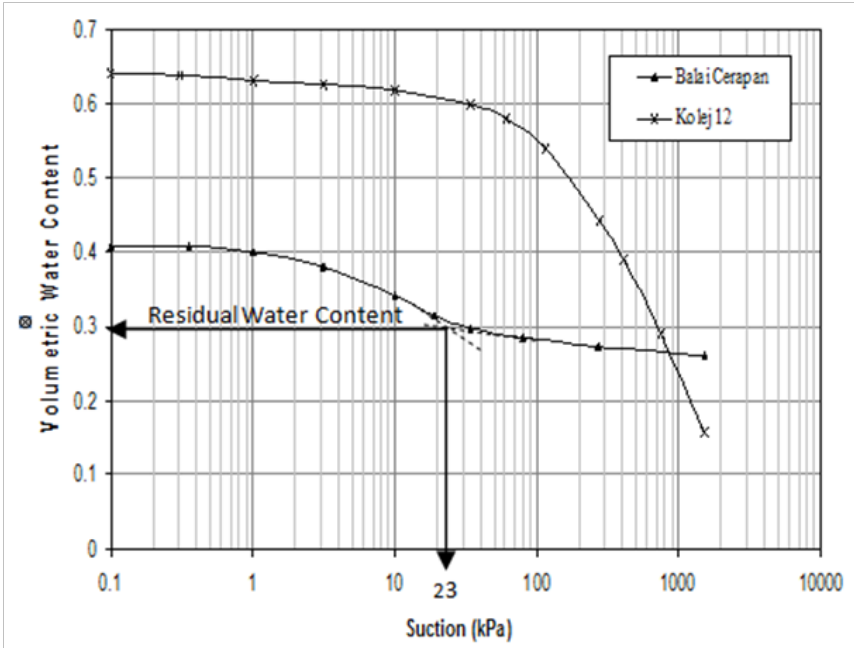

Figure 2 SWCC curves for soils at Site-I (Kolej 12) and Site-2 (Balai Cerapan).

The negative pore water pressure required for the calculation of factor of safety of slope was estimated based on the volumetric water content and the SWCC curve. (Table 2) shows the variation of suction estimated based on SWCC of soils at both sites with depth. Suction was actually measured at depth of $0.5 \mathrm{~m}, 1 \mathrm{~m}$ and $1.5 \mathrm{~m}$. Comparison of the field data and the calculated suction based on SWCC curve shows that the SWCC curve gave higher suction values than the field measurement. However, for normal condition, the trend is similar. This shows that the response of soil to rainfall infiltration is faster than could be predicted by the SWCC curve. Prediction of suction based on water content and SWCC curve for wet condition indicated the reduction of suction; however the trend remained the same in which the suction decreases with depth. In contrast, measurement by tensiometer showed that the suction increases with depth. This discrepancies may be due to the time of measurement whereby tensiometer records the response right after rainfall while the sample obtained for water content determination was taken long time after the rainfall. ${ }^{14-20}$
An interesting point can also be made from this study that the water content of soil at Site-1 remained high even after a long period dry condition. This means that the soil stays at saturated condition due to the accumulation of water caused by low permeability and mineral content of the soil mass. Slope stability analyses were performed for both sites for two conditions i.e. normal and after the prolonged heavy rainfall (extreme) in December 2006. It should be noted that the cumulative rainfall during 4 days before failure occurred at Site- 1 was $489.4 \mathrm{~mm}$ and the maximum rainfall the day before the failure took place was $190.8 \mathrm{~mm}$. Infinite slope procedure was used to determine the Factor of Safety (FOS). The calculation was made for slip planes at different depths between 1 and $2.0 \mathrm{~m}$ with the interval of $0.2 \mathrm{~m}$. Drained shear strength parameters obtained from direct shear test were used in the calculation. The results of the slope stability analysis performed for suction predicted based on water content and SWCC curve are presented in Table 3.

Table 3 The variation of factor of safety with depth

\begin{tabular}{lllll}
\hline \multirow{2}{*}{$\begin{array}{l}\text { Depth } \\
\mathbf{m}\end{array}$} & \multicolumn{2}{l}{ FOS (Site 1) } & \multicolumn{2}{l}{ FOS (Site 2) } \\
\cline { 2 - 5 } & Normal & December & Normal & December \\
\hline 1.0 & 5.45 & 1.14 & 4.79 & 4.08 \\
\hline 1.2 & 4.21 & 1.08 & 4.29 & 3.58 \\
\hline 1.4 & 3.33 & 1.04 & 3.94 & 3.21 \\
\hline 1.6 & 2.66 & 1.01 & 3.68 & 2.97 \\
\hline 1.8 & 2.15 & 0.99 & 3.49 & 2.86 \\
\hline 2.0 & 1.83 & 0.97 & 3.34 & 2.78 \\
\hline
\end{tabular}

Table 3 shows that the slope at Site- 2 remained safe after rainfall, even though there is a decrease in factor of safety with depth. On the other hand, the slope at Site-1 became unstable at depth $1.8 \mathrm{~m}$ (FOS $<1)$ due to increase in water content which is beyond the volumetric water content at saturation. Table 3 shows that at normal condition, the slope Site-1 is more stable than slope at Site-2 for shallower depths, however FOS decreases as water started to accumulate at deeper elevation. Furthermore, the reduction of FOS at all depths at Site-1 is more significant than that at Site-2. It can also be seen from the table that there is a significant reduction of FOS with depth for both locations until a certain value. Then, the FOS becomes almost constant. The depth where the FOS becomes constant is considered as the critical depth. Table 4 shows the FOS obtained from stability analysis for which measured suction were used. Figure 3 show the variation FOS with depth of slip surface for Site-1. The points indicated the FOS obtained for measured suction at depth of 1.0 and $1.5 \mathrm{~m}$. The FOS of slope at Site-1 decreases with depth. At normal condition, the minimum FOS of 1.83 was reached at depth of $2 \mathrm{~m}$. For wettest condition (December), FOS less than 1 was obtained at depth of $1.8 \mathrm{~m}$ which agrees with the observed failure plane.

Table 4 FOS calculated based on measurement data.

\begin{tabular}{lllll}
\hline \multirow{2}{*}{$\begin{array}{l}\text { mepth } \\
\text { FOS (Site-1) }\end{array}$} & \multicolumn{3}{c}{ FOS (Site-2) } \\
\cline { 2 - 5 } & Normal & December & Normal & December \\
\hline 1.0 & 2.97 & 1.14 & 4.43 & 3.48 \\
\hline 1.5 & 2.41 & 1.02 & 3.94 & 3.39 \\
\hline
\end{tabular}

Based on field measurement, the minimum FOS of slope at Site-1 was 2.41 , but decreases significantly to 1.02 at depth $1.5 \mathrm{~m}$ after heavy rainfall in December 2006. The variation of FOS with depth of slip surface for Site-2 is presented in Figure 4. The points indicated the FOS obtained for measured suction at depth of 1.0 and $1.5 \mathrm{~m}$. The figure indicates that the slope at Site-2 (Balai Cerapan) remained 
stable even after the prolonged heavy rainfall. Based on field measurement, the FOS decreased slightly from 3.94 to 3.39 for slip plane at depth of $1.5 \mathrm{~m}$. The FOS calculated based on water content and SWCC curve do not seems to agree with that calculated based on actual measurement of suction by tensiometers, however; the trend is similar. More variation of FOS with depth was obtained from the calculation based on SWCC as compared to the actual measurement. This shows that the actual variation of suction in soil is not as much as that predicted by SWCC curve. There are factors, other than the permeability and SWCC curve, affect the mechanism of rainfall infiltration in soil such as the mineralogy and the dispersibility of the soil. These will be the subject of further study. More attention should be given to the fine-grained soil slope during monsoon season.

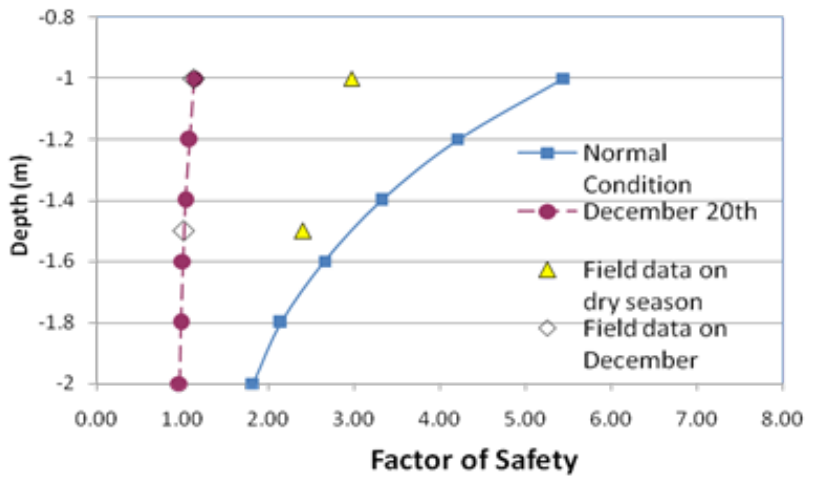

Figure 3 Depth of Slip Plane vs. Factor of Safety for Site-I.

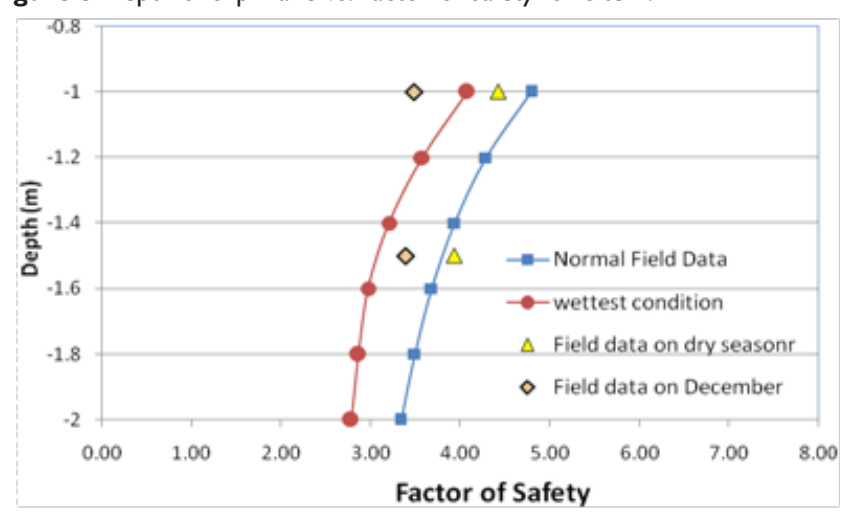

Figure 4 Depth of Slip Plane vs. Factor of Safety for Site-2.

(Figure 5) shows readings at site-1 at three depths for one day rainfall after dry period. The events illustrated same amount and intensity of rainfall, ranged $6-20 \mathrm{~mm} /$ day and $6-15 \mathrm{~mm} /$ hours respectively. Events reflect same response at all depths except events 1 and 4 at depth 1.5 meter does not provide satisfactory explanation to why there is no change in reading $20 \mathrm{kpa}$ and $22 \mathrm{Kpa}$ respectively compare to $20 \mathrm{Kpa}$ and $22 \mathrm{Kpa}$ respectively at depth 0.5 meter. This suggests that there other factor affection water infiltration which is soil permeability as well as the soil accommodated moisture at depth 1.5meter. (Figure 6) shows readings at site-1 at three depths for two days antecedent rainfall. The events illustrated different amount and intensity of rainfall. The 1,2 and 3 events provided high amount and intensity of rainfall 7,15 and $13 \mathrm{~mm}$ respectively while the events 4 , 5 and 6 provided low amount and intensity of rainfall $2.8,1.4$ and $3.4 \mathrm{~mm}$ respectively, even though the soil suction readings at depths 1.0 and 1.5 meter for the events 4,5 and 6 recorded less than readings at depth 0.5 meter. This suggests that highest pore-water pressure profiles are not necessarily produced by the highest individual rainfall event. While the readings at depth 0.5 meter explained that the two days antecedent rainfall with low permeable soil does not has significant change on pore-water pressure at depths below 0.5 meter.

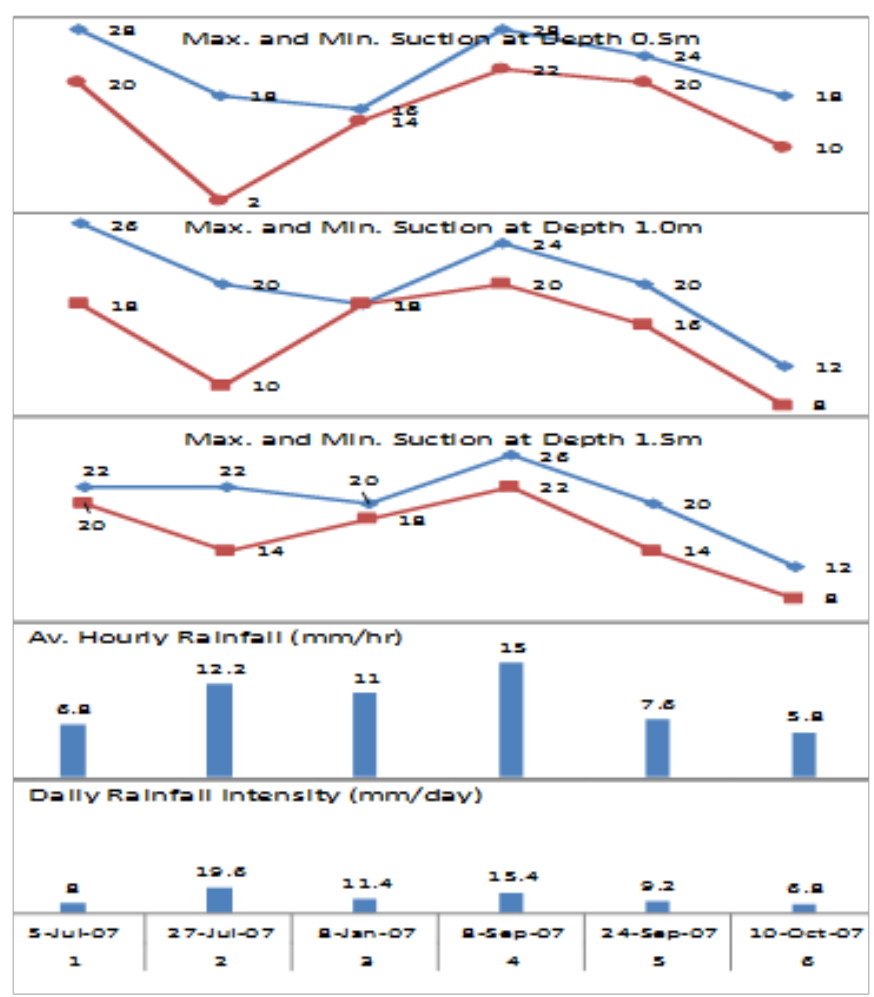

Figure 5 Site-I one day antecedent rainfall.

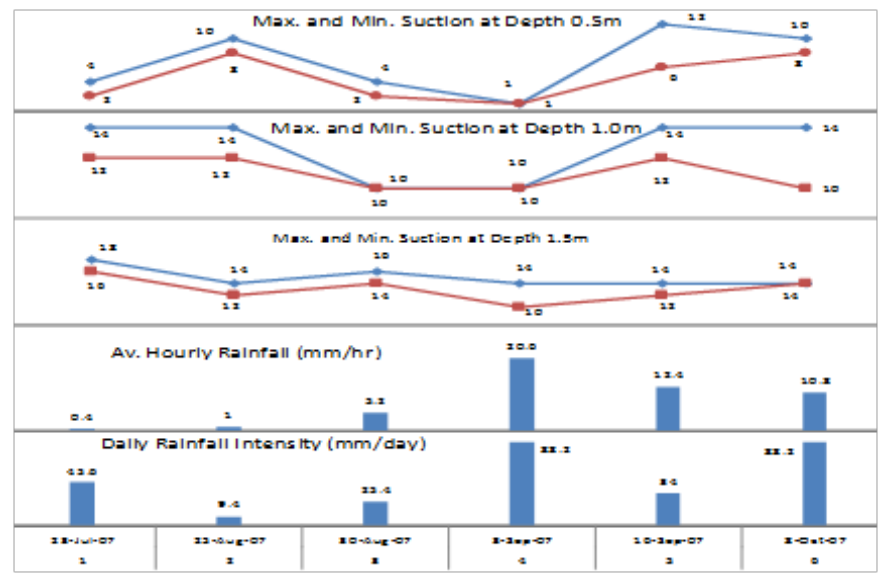

Figure 6 Site-I two days antecedent rainfall.

Figure 7 shows readings at site- 1 at three depths for three days antecedent rainfall. Event 1 experienced significant amount of rainfall $45 \mathrm{~mm}$ with low intensity $0.4 \mathrm{~mm}$ per hour and the soil suction at depths 1.0 and 1.5 meter 12 and $16 \mathrm{Kpa}$ respectively while the reading at depth 0.5 meter is $2 \mathrm{Kpa}$ was changed significantly which provide satisfactory explanation that soil permeability affecting rainfall infiltration and readings at other two depths support the idea that soil accommodated water. Event 6 provide same explanation that water infiltration effect does not reach depth 1.5 meter due to soil permeability while the same readings at depths 1.5 and 1.0 meter 
means the soil accommodated water. Figure 8 shows readings at site1 at three depths for three days antecedent rainfall. The event 1 show 18,16 and $18 \mathrm{Kpa}$ at three depths $0.5,1.0$ and 1.5 meter respectively under low amount of water and no heavy rainfall which means there is no effect at depth 1.0 meter as well as support the idea that the soil accommodated water at level below 1.0meter.

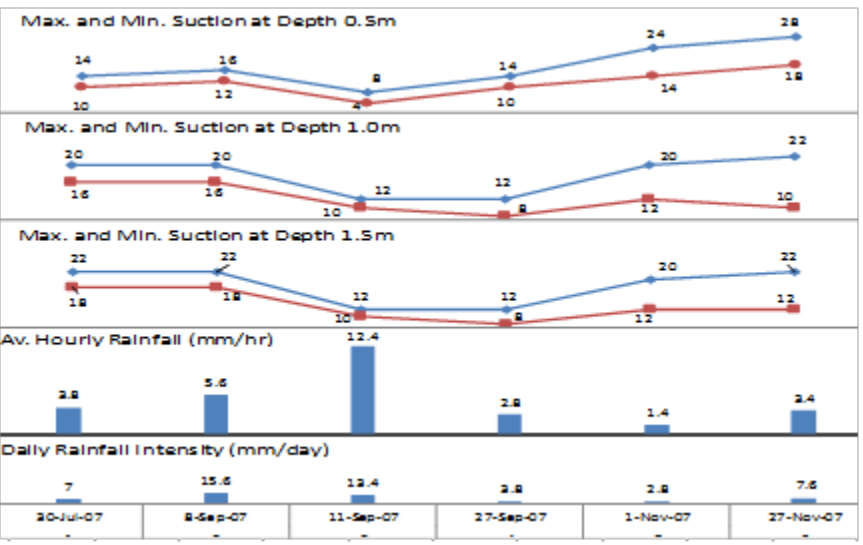

Figure 7 Site-I three days antecedent rainfall.

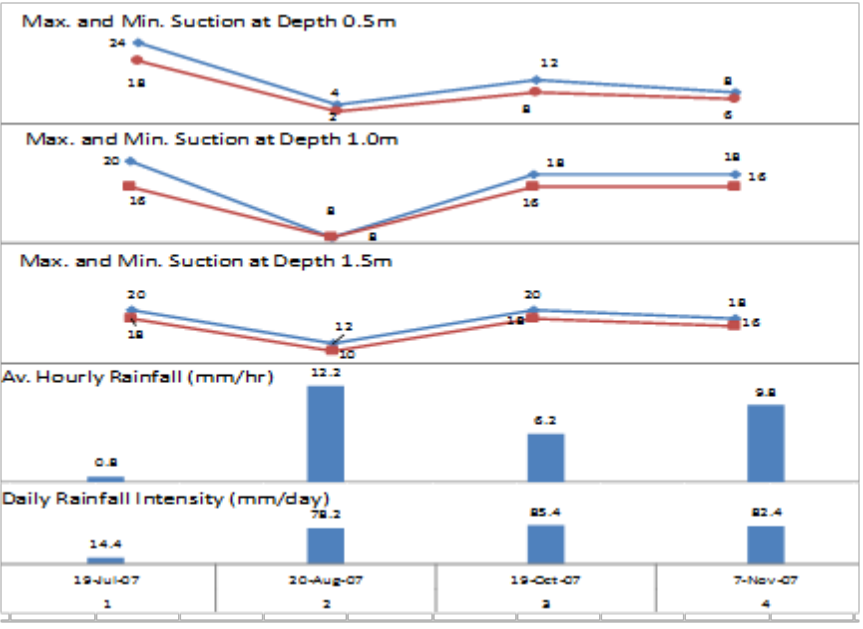

Figure 8 Site-I five days antecedent rainfall.

Figure 9 shows readings at site- 2 at three depths for one day rainfall after dry period. The events $1,2,3,7$ and 10 experience heavy rainfall $59,38,48,37$ and $49 \mathrm{~mm}$ respectively. The soil suction readings at three depths $0.5,1.0$ and 1.5meter ware 2, 6 and 10Kpa respectively. While the other events experienced low rainfall average $10 \mathrm{~mm}$ and the soil suction average at three depths 0.5, 1.0 and 1.5meter ware 5,8 and $14 \mathrm{Kpa}$ respectively. This provides satisfactory explanation that the soil response does not affected by soil permeability as well as there is no water accommodation in soil pores. Figure 10 shows readings at site- 2 at three depths for two days antecedent rainfall. The event 5 experience heavy rainfall $74 \mathrm{~mm}$ while the events 1 and 8 experience rainfall 23 and $30 \mathrm{~mm}$ respectively. The soil suction readings for three events at three depths $0.5,1.0$ and 1.5 meter ware 4, 7 and 12Kpa respectively. While the other events experienced low rainfall average $10 \mathrm{~mm}$ and the soil suction average at three depths $0.5,1.0$ and 1.5 meter ware 5,8 and $14 \mathrm{Kpa}$ respectively, which same response in one day rainfall. This provide satisfactory explanation that for permeable soil the soil response does not reflect difference in reading between one day rainfall and two days rainfall regard less the intensity of rainfall events at depth less than 2.0meter.

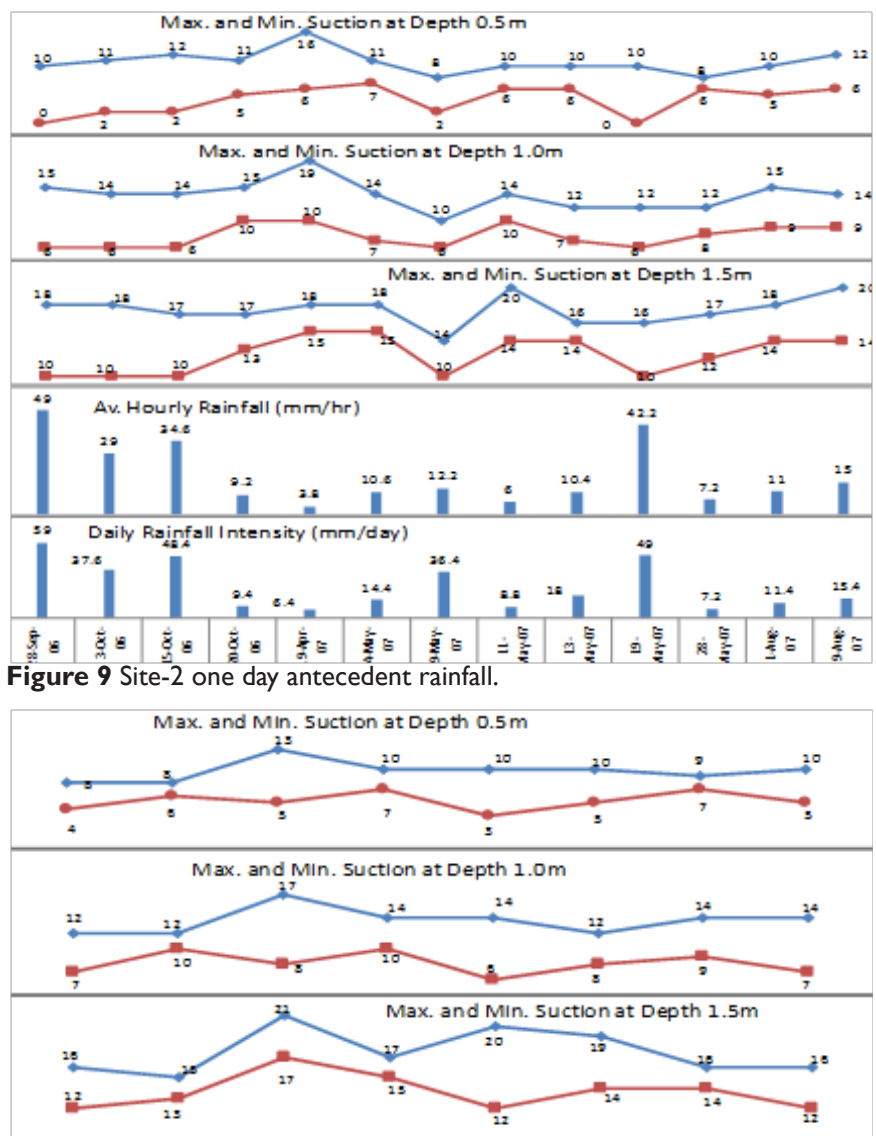

Av. Hourly RaInfall ( $\mathrm{mm} / \mathrm{hr})$

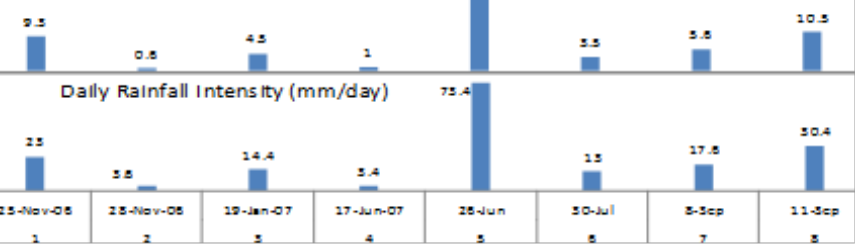

Figure 10 Site-2 two days antecedent rainfall.

Figure 11 shows readings at site- 2 at three depths for three days antecedent rainfall. The event 1, 2, 6 and 9 experience heavy rainfall $59,92,58$ and $88 \mathrm{~mm}$. The soil suction readings for three events at three depths $0.5,1.0$ and 1.5 meter ware 3,7 and $11 \mathrm{Kpa}$ respectively. While the remaining events experienced prolong rainfall with low rainfall intensity ranged between 10 to $46 \mathrm{~mm}$, the soil suction average at three depths $0.5,1.0$ and 1.5 meter ware 5,8 and $14 \mathrm{Kpa}$ respectively, which same response in one day and two days rainfall. Those supporting the previous explanation of (Figure 10).

Figure 12 shows readings at site- 2 at three depths for five days antecedent rainfall. The event 5 and 6 ex-perience heavy rainfall 475 and $370 \mathrm{~mm}$ respectively, with different intensity 23 and $12 \mathrm{~mm}$ per hour respectively. The average soil suction readings for three events at three depths $0.5,1.0$ and 1.5 meter ware 3,7 and $11 \mathrm{Kpa}$ respectively which same readings for three days antecedent rainfall. While the events $1,3,4,8,9,10$ and 12 experienced medium rainfall 120,164, $116,103,133,101$ and 78 respectively, with different rainfall intensity ranged between 10 to $22 \mathrm{~mm}$, the soil suction average readings at three depths $0.5,1.0$ and 1.5 meter ware 5,8 and $11 \mathrm{Kpa}$ respectively. The 
events 2, 7and 11 experienced prolong and low Rainfall 35, 23 and $14 \mathrm{~mm}$ respective. The soil suction average readings at three depths $0.5,1.0$ and 1.5 meter ware 4,7 and $12 \mathrm{Kpa}$ respectively, which same response in one day and two days rainfall. This explains that the antecedent rainfall has no significant effect for high permeable soil comparing low permeable soil.

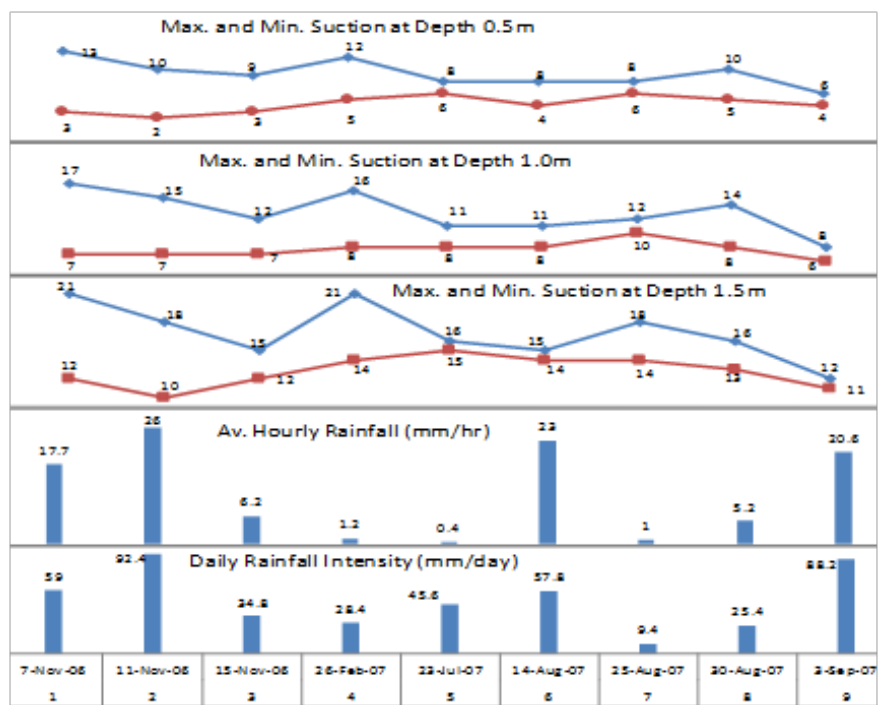

Figure II Site-2 three days antecedent rainfall.

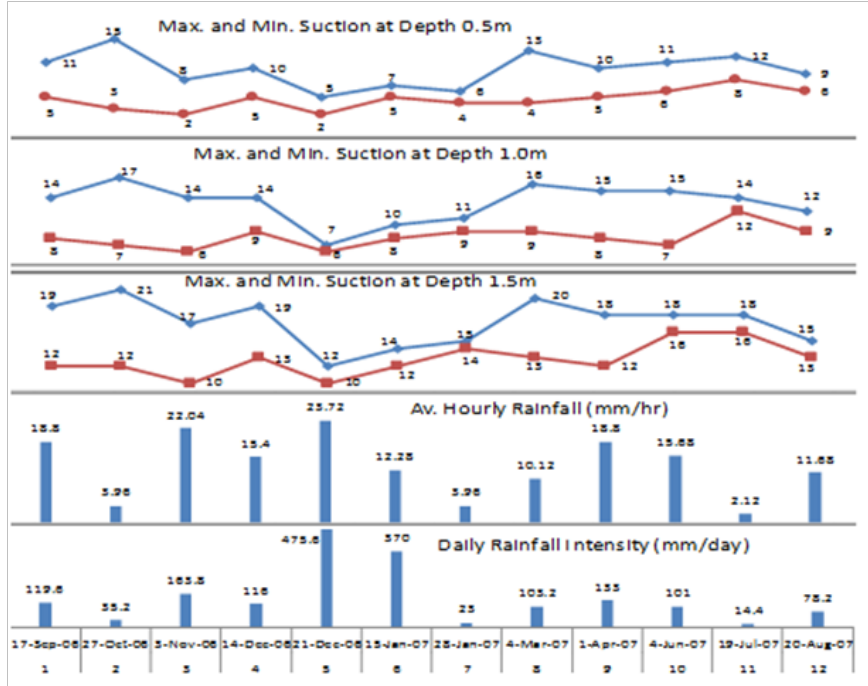

Figure 12 Site-2 five days antecedent rainfall.

\section{Conclusion}

Several conclusions could be derived from the study on the response of soil slopes. Firstly, antecedent rainfall plays more significant role in residual soils with lower permeably than those with higher permeability in producing the highest pore-water pressure profile in a slope. Secondly, it was observed that, in all the slopes monitored the highest pore-water pressure profile was reached when the total rainfall including 5-day antecedent rainfall was a maximum. Thirdly, residual soils with low fines and high permeably pore-water pressure variation could take place over a wide range while in residual soils with relatively low fines and high permeably pore-water pressure variation occurs over a narrow range. Fourthly, factor of safety varied rainfall magnitude for all slopes. On this consideration it appears that the factor of safety of residual soil slopes with relatively low permeability are unaffected by the worst pore-water pressures. Fifthly, shallow slope failures are dominated by the combination of transient pore pressure in response to rainfall infiltration. Six, The SWCC can be used to estimate the highest suction that may be reached in a soil slope and the fluctuation range of the suction.

\section{Acknowledgments}

None.

\section{Conflict of interest}

Author declares that there is no conflict of interest.

\section{References}

1. Barata. Landslides in tropical region of Rio de Jabeiro. Proceedings of the 7th International Conference on Soil Mechanics and Foundation Engineerin. 1969;2:507-16.

2. Lim TT. Effect of rainfall on metric suctions in a residual soil slope Canadian Geotechnical J. 1996;33:618-628.

3. Crosta. Regionalization of rainfall thresholds, an aid to landslide hazard evaluation. Environmental Geology.1998;35(2-3):131-145.

4. Rahardjo H, Li XW, Toll DC, et al. The effect of antecedent rainfall on slope stability. Geotechnical and Geological Engineering. 2001;19(3-4):371-399.

5. Fukuoka M. Landslides associated with rainfall. Geotechnical Engineering. J Southeast Asian Geotechnical Society. 1980;11:1-29.

6. Brand. Landslides in Southeast Asia: a state-of-the-art report. Proceedings of the 4th International Symposium on Landslides. Canada: Canadian Geotechnical Society; 1984. p. 17-59.

7. Eyles. Slip-triggering rainfalls in Wellington city. New Zealand $J$ Science. 1979;22:117-121.

8. Crozier, Eyles. Assessing the probability of rapid mass movement. Proceedings of the 3rd Australia-New Zealand Conference on Geomechanics. 1980:2:47-51.

9. Lumb. Slope failures in Hong Kong. Quarterly J Engineering Geology. 1975;8:31-65.

10. Fredlund. The Shear Strength of Unsaturated Soils. Canadian Geotechnic J. 1978;15:313-321

11. Sung, Seung. Evaluation of Surficial Stability for Ho-mogeneous Slopes Considering Rainfall Characteristics. J Geotechnical \& Geoenvironmental Engineering. 2002;128(9):756-763.

12. Gofar. Stability of Unsaturated Slopes Subjected to Rainfall Infiltration. Proceedings of the 4th International Conference on Disaster Prevention and Rehabilitation. 2007:10-11.

13. Ost. Characteristics and spatial distribution of large landslides in the Flemish Ardennes. Zeitschrift fur Geomorphologie. 2003;47(3):329350 .

14. Azlan. Collapsibility and Volume Change Behavior of Unsaturated Residual Soil. American J Environ-mental Sciences. 2006;2(4):161166.

15. Basile. Soil hydraulic behavior of a selected benchmark soil involved in the landslide of Sarno. 1998;117(34):331-346. 
16. Cai, Ugai. Numerical Analysis of Rainfall Effects on Slope Stability. International J Geomechanics. 2004;4(2):69-78.

17. Fredlund. Nonlinearity of Strength Envelope for Unsaturated Soils. Proc 6th Intl Conf on Expansive Soils. 1987:49-54.

18. Pradel, Raad. Effect of Permeability on Surficial Stability of Homogeneous Slopes. $J$ Geotechnical En-gineering. $1993 ; 119(2): 315-332$.
19. Wang, Benson. Leak-Free Pressure Plate Extractor For Measuring the Soil Water Characteristic Curve. Geo-technical Testing J. 2004;27(2).

20. Fredlund DG, Rahardjo H. Soil Mechanics for Unsaturated Soil. London: Wiley; 1997. 